7. Reprod. Fert. (1972) 28, 265-267

\title{
RESISTANCE OF THE RAT EMBRYO TO LIGATION OF A UTERINE ARTERY EARLY IN GESTATION
}

\author{
N. W. BRUCE* \\ School of Veterinary Science, University of Melbourne, Parkville, Victoria, Australia
}

(Received 26th May 1971, accepted 27th Fuly 1971)

\begin{abstract}
Summary. The left uterine artery was ligated in 1-, 2- and 7-day pregnant rats to determine the effects on conceptuses at Day 22. Uterine arterial ligation at these stages of gestation had no apparent effect on the percentage of rats holding to service, on fetal survival, the incidence of fetal malformation, fetal sex ratios or fetal weights.
\end{abstract}

In a study on the effect of restricted uterine blood flow on embryonic development, a method of cannulating and, thus, of occluding the left uterine artery of pregnant rats without affecting their conceptuses was required. Wigglesworth (1964) had shown that ligation of the uterine artery and vein of 17-day pregnant rats caused fetal resorption and growth retardation. Senger, Lose \& Ulberg (1967) reported that cauterization of some of the vessels supplying the uterine horn of the mouse 1 and 5 days after mating greatly reduced the number of ova implanting. In view of these findings, it was decided to test the effect of occluding the uterine artery at stages of gestation when the conceptus might be expected to survive sudden changes in the uterine circulation, relying on the development of existing anastomotic vessels from the ovarian and vesical arteries to provide for its later needs.

Sixty-five Albino Wistar rats, with a mean weight of $195 \mathrm{~g}$ at mating, were anaesthetized by an intraperitoneal injection of $35 \mathrm{mg} / \mathrm{kg}$ Veterinary Nembutal (Abbott Laboratories Ltd), on Days 1, 2 or 7 of gestation (the day on which spermatozoa were found in a vaginal smear was designated Day 1). A ventral midline incision was made, the uterus was examined and on Day 7, a record was also made of the number and position in the horn of each implantation site. Rats with less than two or more than eight implantation sites in their left horns were discarded at this stage. Two ligatures were then tied, $1 \mathrm{~cm}$ apart, round the left uterine artery (referred to by Greene, 1955, as the vesical artery) close to its origin from the common iliac artery, and the section between the ligatures was excised to inhibit revascularization: from this source. The right uterine horn was handled in a similar fashion but its artery was not ligated to serve as a control. The incision was closed and the rat was allowed to recover and continue its pregnancy undisturbed until Day 22, the day before expected parturition. It was then killed, its uterus was examined, and a record was made of each implantation site indicated by a metrial gland. The fetuses were removed and

* Present address: The Nuffield Institute for Medical Research, University of Oxford, Headington, Oxford. 
examined for viability, incidence of external malformation and weight. All rats treated were included to provide measures of pregnancy rates but only the first ten in each group, found to be pregnant on Day 22, were used to establish fetal survival, malformation rates and mean fetal weights.

At all three stages of gestation, ligation of the uterine artery had no apparent effect on pregnancy rate, fetal survival, incidence of fetal malformation or sex ratios (Table 1). Chi-square tests for independence confirmed that there were no significant differences in these values between the three groups, or between treated and control horns within each group. There was no consistent effect on mean fetal weights. The difference between mean fetal weights in the control

TABLE 1

EFFEGTS OF UTERINE ARTERIAL LIGATION ON EMBRYONIG DEVELOPMENT

\begin{tabular}{|c|c|c|c|c|c|c|}
\hline & \multicolumn{6}{|c|}{ Treated on gestational day } \\
\hline & \multicolumn{2}{|c|}{1} & \multicolumn{2}{|c|}{2} & \multicolumn{2}{|c|}{7} \\
\hline $\begin{array}{l}\text { No. of rats treated } \\
\text { No. pregnant (Day } 7) \\
\text { No. pregnant (Day 22) } \\
\text { Pregnancy rate }(\%)^{*}\end{array}$ & \multicolumn{2}{|c|}{$\begin{array}{l}25 \\
18 \\
72\end{array}$} & \multicolumn{2}{|c|}{$\begin{array}{l}16 \\
12 \\
75\end{array}$} & \multicolumn{2}{|c|}{$\begin{array}{l}24 \\
16 \\
16 \\
67\end{array}$} \\
\hline Uterine horn & Treated & Control & Treated & Control & Treated & Control \\
\hline $\begin{array}{l}\text { No. of metrial glands (Day } \\
22 \text { ) } \\
\text { No. of live fetuses (Day 22) } \\
\text { Fetal survival (\%) } † \\
\text { No. malformed } \\
\text { Male: female, sex ratio } \\
\text { Mean fetal weight (g) } \\
\pm \text { S.E. }\end{array}$ & $\begin{array}{c}47 \\
33 \\
70 \\
0 \\
15: 18 \\
3.96 \\
\pm 0.08\end{array}$ & $\begin{array}{r}47 \\
36 \\
77 \\
1 \\
19: 17 \\
4.07 \\
+0.07\end{array}$ & $\begin{array}{c}53 \\
38 \\
72 \\
2 \\
14: 24 \\
3.92 \\
\pm 0.08\end{array}$ & $\begin{array}{c}41 \\
30 \\
73 \\
0 \\
14: 16 \\
4.07 \\
\pm 0 \cdot 14\end{array}$ & $\begin{array}{c}49 \\
37 \\
76 \\
0 \\
24: 13 \\
4 \cdot 29 \\
+0 \cdot 07\end{array}$ & $\begin{array}{c}30 \\
24 \\
80 \\
0 \\
14: 10 \\
4 \cdot 18 \\
\pm 0 \cdot 11 \\
\end{array}$ \\
\hline $\begin{array}{l}\text { Gontrol horn minus treated } \\
\text { horn mean fetal weight }(g)\end{array}$ & \multicolumn{2}{|c|}{$+0 \cdot 11$} & \multicolumn{2}{|c|}{$+0 \cdot 15$} & \multicolumn{2}{|c|}{$-0 \cdot 11$} \\
\hline
\end{tabular}

$$
\begin{aligned}
& * \text { Pregnancy rate }(\%)=\frac{\text { No. pregnant on Day } 22}{\text { Total no. treated }} \times 100 . \\
& \dagger \text { Fetal survival }(\%)=\frac{\text { No. of live fetuses }(\text { Day } 22)}{\text { No. of metrial glands }(\text { Day } 22)} \times 100 .
\end{aligned}
$$

and treated horns ranged from $+0.15 \mathrm{~g}$ to $-0.11 \mathrm{~g}$, but these differences were not statistically significant.

These results show that at some stages in gestation the uterine artery can be occluded by ligation and partial resection without appreciably affecting pregnancy. On Days 1 and 2, the ova are still in the oviduct and remain there until Day 4 of gestation (Dickman \& Noyes, 1960). It seems reasonable that, after ligation on Days 1 or 2 , the anastomotic ovarian and vesical vessels to the uterus would have sufficient time to adjust to meet the demands of implantation on Day 6 and the subsequent growth of the conceptus. The finding that, on Day 7, ligation of the uterine artery again had no apparent effect was more surprising. At this stage, implantation and the decidual reaction have taken 
place, development of the ectoplacental cone and differentiation of the embryonic cell mass have commenced (Enders \& Schlafke, 1967). It must be concluded that either these structures are resistant to sudden changes in the circulation or that the ovarian and vesical anastomotic vessels can provide a larger percentage of the uterine circulation than one would expect from their anatomical appearance at this stage. These vessels are evidently sufficient to provide for the normal growth and maintenance of conceptuses throughout pregnancy, since very little revascularization by way of the ligated artery was observed.

This study formed part of a Ph.D. thesis submitted for examination to the University of Melbourne in February 1971. I acknowledge with gratitude the constant advice and encouragement of $\mathrm{Dr} \mathrm{J}$. Watson.

\section{REFERENCES}

Dickmann, Z. \& Noyes, R. W. (1960) The fate of ova transferred into the uterus of the rat. F. Reprod. Fert. 1, 197.

ENDERS, A. C. \& SCHLAFKe, S. (1967) A morphological analysis of the early implantation stages in the rat. Am. F. Anat. 120, 185.

Greene, E. C. (1955) Anatomy of the rat. Hafner, New York.

Senger, P. L., Lose, E. D. \& Ulberg, L. C. (1967) Reduced blood supply to the uterus as a cause for early embryonic death in the mouse. $\mathcal{F}$. exp. Zool. 165, 337.

WrgGlesworth, J. S. (1964) Experimental growth retardation in the foetal rat. F. Path. Bact. 88, 1. 